\title{
BOOK REVIEWS / BOEKRESENSIES
}

Roy A. Harrisville, Pandora's Box Opened: An Examination and Defense of Historical-Critical Method and Its Master Practitioners. Grand Rapids, MI, Cambridge, U.K.: Eerdmans, 2014. x + 358 pages. Paperback. Price US\$42.00. ISBN 978-0-8028-6980-7.

Roy A. Harrisville likens the historical-critical method to the contents in Pandora's box, which, when opened, released "a myriad other pains." This was then due to "methodological vagaries of the generations" (p. viii). He points out that there is no longer agreement on the historical-critical method amongst biblical interpreters, not as there used to be when it aimed to determine the historical and authorial intended meaning of the biblical texts. However, Harrisville is optimistic that hope remains for the historical-critical method, but what this hope is, and what guise it would take, is never fully discussed.

Pandora's Box Opened was stimulated by and grew from a series of lectures that Harrisville presented at Luther Seminary in 2007 (p. x), and as a result, it unfortunately reads like material strung together, which is not well integrated, making the book lack clear direction.

In the first seven chapters, Harrisville's book consists of short overviews of the perspectives and contributions of various scholars who wrote on the historical study of the Bible. In all fairness, Harrisville writes in the book's Preface (pp. vii-viii) that

the appearance of some and the absence of others may strike the reader as odd. More yet, some of the selection has been purely subjective, due to an interest in this or that personage, to the effect that the only thing each cluster of researchers and scholars share is the period, and roughly the period, in which they lived.

Harrisville is careful not to caricature the figures he discusses by making mention of their significant contemporaries and by relying on primary sources for his analysis of each one. After comparatively brief treatments of interpretative methods in ancient history, the Reformation era, and the period of Protestant Orthodoxy and Pietism, Harrisville pays most attention to the Enlightenment, the Modern Period, and the 20th century. He treats the interpretive positions of well-known and lesser-known figures. Examples include, amongst others, Luther, Calvin, and Müntzer (in ch. 2); Illyricus and Bengel (in ch. 3); Spinoza, Locke, Wolff, Baumgartner (in ch. 4); Hamann and Edelmann (in ch. 5); Semler, Schleiermacher, the Strauss-Bauer School, and a

* Doi for all book reviews in this issue: http://dx.doi.org/10.17159/2312$\underline{3621 / 2017 / v 30 n 2 a 20}$ 
selection of American scholars (in ch. 6); and Barth, Bultmann, and the perspectives of four American schools (in ch. 7). In ch. 8, titled Summing Up, Harrisville provides a brief yet effective summary of the preceding seven. The historical outline of Harrisville's book makes up a total of 277 pages (chs. 1-8, pp. 1-277), whereas the actual critical reflection on the historical-critical method only occupies 72 pages (chs. 9-11, pp. 278-350). The book is largely then more of a historical examination than a defence.

In ch. 9, titled The Malaise, Harrisville describes the attacks on the historical-critical method, points out only some of the alternatives to it, and states what the current situation is. In ch. 10, titled The Historical-Critical Method Down to Size, he commends a version of the historical-critical method which is shorn of its previous arrogance and calls for its continuance in a cautious manner. He thus finds hope for the historical-critical method's future, especially in the views of the likes of his former teacher, Otto Piper. As the gospel emerged out of historical reality, we need a method that would focus on that reality. As biblical religion arose out of God's historical dealing with humankind, the historical-critical method still has its place on the exegetical spectrum. Harrisville concludes Pandora's Box Opened with “The Bible will have its way because of the Word of God it attests” (p. 350).

Sadly, Harrisville's attempt at the historical-critical method's defence does not effectively counter the critique that has been levelled against it. Thus, the reader who is in search of a critical defence and revival of the historicalcritical method will not find it in Pandora's Box Opened. However, the book can be recommended for the graduate student who is unacquainted with the history behind the historical(-critical) study of the Bible as Harrisville breaks down complicated concepts into digestible units in his overviews of prominent figure's contributions in this regard.

Jo-Marí Schäder, Department of Ancient Languages and Cultures, University of Pretoria.E-mail: jo-mari.schader@up.ac.za.

Allison, Dale C., Christine Helmer, Steven L. McKenzie, Thomas Römer, Jens Schröter, Choon-Leong Seow, Barry Dov Walfish, Eric Ziolkowski (eds.). Encyclopedia of the Bible and its Reception 11: Halah - Hizquni (Berlin, Boston: de Gruyter, 2015). Xxix + 1200 cols., hardbound. ISBN 978-3-11031328-4. 238 Euro

The eleventh volume of the Encyclopedia of the Bible and Its Reception (EBR) contains entries from Halah (one of the areas of deportation after the Assyrian conquest of Samaria mentioned in 2 Kgs 17:6; 18:11 and 1 Chr 5:26) to Hizquni (a cross-reference to Hezekiah ben Manoah; see Joseph Priel, “Hezekiah ben Manoah,” 1007-1009). Like the previous volumes, volume 11 
combines what one would expect of a classical Bible dictionary (including references to the ANE) with a broad survey of the reception of biblical material in the NT, Judaism, Christianity, Islam, literature, visual arts, music and film.

The entries on "Hallelujah" and "High Priest” serve as examples of this approach. They consist of a number of sub-entries:

Scott C. Jones, “Hallelujah I: Hebrew Bible/Old Testament” (p. 41), Jan G. van der Watt, "Hallelujah II: New Testament” (pp. 41f); Ruth Langer, "Hallelujah III: Judaism” (pp. 43f); Jürgen Bärsch, "Hallelujah IV: Christianity” (pp. 44-46); Andrew Sharp, "Hallelujah V: Islam” (pp. 46f); Lisa LeBlanc, "Hallelujah VI. Literature" (pp. 47f); Marsha Bryan Edelman, "Hallelujah VII: Music A: Jewish” (pp. 48f); Nils Holger Petersen, "Hallelujah VII: Music B: Christian and General” (pp. 49-54) and LeRhonda S. ManigaultBryant, “Hallelujah VIII: Film” (pp. 54-56).

Karl William Weyde, “High Priest I: Hebrew Bible/Old Testament” (pp. 1045-1947); David M. Moffitt, "High Priest II: New Testament” (pp. 10471049); Joseph Angel, "High Priest III: Judaism A: Second Temple and Hellenistic Judaism” (pp. 1049-1052); Jonathan Klawans, "High Priest III: Judaism B: Rabbinic Judaism” (pp. 1052f); Susanne Talabardon, "High Priest III: Judaism C: Medieval and Modern Judaism” (pp. 1054f); Martin Karrer, "High Priest IV: Christianity” (pp. 1056f); Melissa Weininger, "High Priest V: Literature” (pp. 1057-1059); Ari P. Cohen, “High Priest VI: Visual Arts” (p. 1059) and "High Priest VII: Film” (pp. 1059-1061).

The obvious strength of this approach is that each sub-field can be assigned to specialists, given that mastery of the whole range of biblical evidence and its reception is beyond individual scholars. However, this approach results in a lack of coherence and synthesis. The interpretation of this mass of information and the search for trajectories are left to the reader.

Of particular interest for the study of the OT are the following longer entries from the first 400 columns of this volume (not including names of minor places or persons). Our focus is on the OT itself, not on the reception history of the biblical material, which is described in the following sub-entries (as above with Hallelujah or High Priest):

Lawrence H. Schiffman, "Halakah I: Judaism A. Second Temple and Hellenistic Judaism” (pp. 1-7); Alyssa Gray, "Halakhah I: Judaism B: Rabbinic Judaism” (pp. 7-12); Ephraim Kanarfogel, "Halakah I: Judaism C: Medieval Judaism” (pp. 12-19); Joseph Davis, “Halakah I: Judaism D: Early Modern Judaism” (pp. 19f); Benjamin Brown, "Halakah I: Judaism E: Modern Judaism” (pp. 20-27); Kitty Millet, "Halakah II: Literature” (pp. 27-31); Kathryn Schifferdecker, "Haman I: I: Hebrew Bible/Old Testament” (pp. 80f); Rami Arav, "Hammath-Gader” (pp. 113-116); Davis Bosworth, "Hammer I: 
Hebrew Bible/Old Testament” (pp. 116f); Andrea Seri, “Hammurabi” (pp. 148152); Juha Pakkala, "Hananiah” (pp. 161-166); Beate Pongratz and Nancy Highcock, "Hand, Hands I: Ancient Near East" (pp. 166-171); Kirstin Wendland, "Hands II: Hebrew Bible/Old Testament” (pp. 171f); Karen Sonik, "Hand of God I: Ancient Near East” (pp. 183f); Johannes Schnocks, "Hand of God II: Hebrew Bible/Old Testament” (pp. 185-187); Corinna Körting, "Hands, Laying on of" (pp. 202f); David W. Chapman, "Hanging and Impalement I: Ancient Near East and Hebrew Bible/Old Testament” (pp. 212215); Jürg Hutzli, "Hannah (Mother of Samuel" (pp. 231-233); Melanie Köhlmoos, "Happiness I: Hebrew Bible/Old Testament” (pp. 276-278); Jürgen Tubach, "Haran I: Ancient Near East and Hebrew Bible/Old Testament” (pp. 291-298); Naama Zahavi-Ely, "Harvest, Harvesting I: Hebrew Bible/Old Testament” (pp. 339-341); Johannes Schnocks, "Hasid, Hasidism I: Hebrew Bible/Old Testament” (pp. 354f) and Rob Barrett, "Hate, Hatred I: Hebrew Bible/Old Testament” (pp. 386f).

Other important entries in this volume cover Hazor, head, healing miracles, hearing/listening, heart, heaven, heaven, gates of, Hebrew grammar, Hebrew inscriptions, Hebrew language, Hebrew script, Hebrew, Hebrews, Hebrews, Epistle to the, Hebron, heir, hell, Hellenism, Hellenisation, Hellenistic Jewish literature, help, heresy, hermeneutics, hero/heroes, hesed, Hexateuch, Hezekiah, hiddenness of God, higher criticism, historical novel, historical critical method, historiography and the Hittites.

The entry "Ham (Person)" also contains several subsections: Markus Witte, "Ham (Person) I: Hebrew Bible/Old Testament" (pp. 62-64) and Michael G. Wechsler, "Ham (Person) II: Judaism” (pp. 64-71). "Ham (Person) III: Christianity” appears in three subsections: Dennis W. Jowers, "A. Patristics, Medieval Times and Reformation Era” (pp. 71-73), Sylvester A. Johnson, "B: Modern America” (pp. 73-75) and Clyde R. Forsberg, "New Christian Churches and Movements” (p. 75). Johnson describes reception of Ham in the context of debates about slavery by both white and black people and the role of Afro-Americans in North America. Forsberg starts with an excellent summary of hermeneutic issues:

The principal work of exegetes and commentators has been an attempt to draw a straight line between the curse of Canaan and race, or skin colour, despite the fact that the Bible makes no such connection. Egypt is referenced in the Bible as "the land of Ham" (Pss 78:51; 105:23, 27; 106:22; 1 Chr 4:40). The names of Ham's other children are thought to allude to Egypt: Mizraim, one of them, is the Hebrew name for Egypt, and Cush, another, is the Hebrew word for black. The proper noun Ham, according to some interpreters, comes from the Egyptian name for Egypt, Kernet, or "black land," Ham also means "hot" or "burnt" in Hebrew. In Jewish folklore, Ham is cursed with blackness for disobeying the prohibition against sex on the ark ... Under Islam, the curse 
is said to justify the enslavement of Africans by Muslims, and medieval Europe followed suit, tarring serfs with the same brush ... Black Coptic Christians and their cultured defenders have consistently rejected any connection to Ham (p. 75).

Then he turns (again!) to the role which the curse of Ham has played in England and the United States vis-à-vis the character and destiny of people of African descent. With due respect to Europe and North America, but there is not a single line on the significance of such interpretations and discussions on African soil. That the figure of Ham featured in some highly problematic discourse in Africa becomes clear from, for example, Elelwani B. Farisani, "Interpreting the Bible in the Context of Apartheid and Beyond: An African Perspective," SHE 40/2 (2014): 207-225 and James A. Loubser, The Apartheid Bible: A Critical Review of Racial Theology in South Africa (Cape Town: Maskew-Miller Longman, 1987).

Like many other instances in this and in previous volumes, the analysis of the reception of the Bible is often limited to Europe and North America. While Afro-American receptions are often mentioned (by North American authors), other parts of the work appear only rarely.

The other sub-entries on Ham are Jaako Hämeen-Antilla, "Ham (Person) IV: Islam” (p. 76); Sylvester A. Johnson, ““Ham (Person) V: Literature” (pp. 76-78); Lee M. Jefferson, "Ham (Person) VI: Visual Arts” (p. 78); Anton Karl Kozlovic, "Ham (Person) VII: Film (pp. 78-80).

Some other observations from my cursory reading of EBR XI: The entry "Hammer I: Hebrew Bible/Old Testament” (David Bosworth, pp. 116f) does not mention that God's word can be likened to a hammer: "is my word not like a hammer that breaks the rock in pieces” (Jer 23:29). I looked in vain for Gunnar Samuelsson, Crucifixion in Antiquity: An Inquiry into the Background and Significance of the New Testament Terminology of Crucifixion, WUNT II.310 (Tübingen: Mohr Siebeck, 2011) in Dale C. Allison’s bibliography on "Hanging and Impalement II: New Testament" (pp. 215f). The entry on "Harnack, Adolf von" (Peter Grove, pp. 321-323) should also mention in the bibliography Harnack's monograph Über den privaten Gebrauch der Heiligen Schriften in der alten Kirche, BENT 5 (Leipzig, Hinrichs, 1912) - after all, this is the Encyclopedia of the Bible and Its Reception. "Heavenly Ladder I: Visual Arts” (John Lansdowne, pp. 596f) could have referred to Ernst Barlach's wood cut of the broken heavenly ladder in his Der göttliche Bettler (Werkverzeichnis Laur I 069.06, online http://www.ernst-barlach.com/gr-069-06-goettlichebettler.html,) as part of his cycle Die Wandlungen Gottes of 1919/1921. The entry "Hebraica Veritas" (Frans von Liere, pp. 608-610) traces Jerome's famous designation of the HB up to Paul of Burgos (died 1431). The following entry, "Hebraism (Christian)" (Jeffrey S. Shoulson, 610-613) addresses "The phenomenon known as Christian Hebraism, the study of Hebrew and Jewish 
texts by Christian scholars” (p. 610). It starts with Origen’s Hexapla and stops in the 17th century (Felix Albrecht, "Hexapla of Origin,” pp. 1000-1002). With the scope of the $E B R$, one would have expected more on the reception of the OT in the Letter to the Hebrews (Martin Karren, "Hebrews, Epistle to the," pp. 680-685). Would the strong intertextuality of the letter not deserve a section of its own? For some reason, Craig C. Hill's entry on the "Hellenists" (pp. 796799) does not include M. Zugmann, "Hellenisten” in Der Apostelgeschichte: Historische und exegetische Untersuchungen zu Apg 6,1; 9,29, 11,20, WUNT II.264 (Tübingen: Mohr Siebeck, 2009) in the bibliography.

Despite these criticisms, EBR XI - like the previous ten volumes - offers a wealth of material which would be difficult to find elsewhere for biblical scholars and all who are interested in the rich and variegated reception of the Bible.

On the reception of the Bible in early Judaism (both "Palestinian" and "Hellenistic"), the recent excellent handbook should be noted: Folker Siegert, Einleitung in die hellenistisch-jüdische Literatur: Apokrypha, Pseudepigrapha and Fragmente verlorener Autorenwerke (Berlin: De Gruyter, 2016).

The reception of the Bible in film has now been documented in some detail in Rhonda Burnette-Bletsch, ed., The Bible in Motion: A Handbook of the Bible and Its Reception in Film, 2 vols., Handbooks of the Bible and Its Reception (Berlin: de Gruyter, 2016), which covers biblical characters and stories (HB), different film genres and styles, biblical themes and genres, biblical characters and stories (NT), cinemas and auteurs and voices from the margin (a full review is to follow).

Christoph Stenschke, Biblisch-Theologische Akademie Wiedenest and Department of Biblical and Ancient Studies, University of South Africa, P. O. Box 392, Pretoria, 0003. Republic of South Africa. E-mail: Stenschke@wiedenest.de.

John E. Toews, The story of Original Sin. Cambridge: James Clarke \& Co, 2013. Paperback. xii + 132 Pages. Price: Paperback and PDF £17.50 US\$35.00 ISBN Paperback 978-0-227-17414-2, PDF 978-0-227-90192-2..

The author, Academic Dean and Professor emeritus of NT Literature at the Fresno Pacific University Biblical Seminary, writes this book at the conclusion of his teaching career, which he ended as President of Conrad Grebel University College at the University of Waterloo. Having completed his theological training in a conservative evangelical setting, Toews returns in this study to a question that has troubled him since his senior year in the Christian liberal arts college which he attended. The flavour of penal substitution 
presented to Toews in this context taught that the original sin into which he had been born necessitated forgiveness that was made possible by the death of Christ. This view of original sin rested heavily on a particular reading of the Eden narrative, and its ontological view of sin finds its soteriological counterpart in the necessity of the Virgin Birth of Jesus, so that the male could be removed from the reproductive cycle, with the result that the transmission of sin could be stopped. The dialogical relation between sin and redemption explains why the detrimental effects of a distortion in one of the doctrines often only becomes visible in the effect it has on the other. It is for this reason, and due to the fact of the central place of soteriology in Christian religion, that Toew's study is one that bears extreme relevance to the church. Toew's remark that his theological education trained him to understand sin as an ontological reality (i.e. "that I was sinful by nature apart from any choice or action of my choosing,” p. 3) is highly significant, in that such a view will of necessity find its soteriological counterpart in a view of salvation as a similarly ontological act made possible by the cross of Christ.

Toew's early theological training was followed in his doctoral studies in NT by an understanding of the role that history and tradition plays in our reading of texts, and of the "paradigmatic effect on biblical interpretation of people like Constantine and Augustine” (p. 3). This book, then, had its origin in Toew's early discomfort with the teaching of original sin, coupled with the disconnect that he saw between Paul's view of sin and Augustine's interpretation of this in Rom 5:12. Finally, it were the many critical discussion that he had over many years with theological students, and even his own son, who is a biochemist and found the doctrine of original sin scientifically untenable, that led him to once again bring pen to paper at the conclusion of his theological career.

In Chapter One, The Story of Sin in Genesis 3, Toews reads what is traditionally interpreted as a narrative of the "Fall" as a crime and punishment narrative that had its origin somewhere between the 10th century BCE. and Israel's exile in the 6th century BCE. Adam and Eve's "sin" (a word that he rightly points out is nowhere to be found in the narrative), consists of their mistrust and disobedience of God. As a result of this, although they do not die, a great change follows in that they are now consciously naked and afraid to meet God. Their expulsion from the garden - both as punishment and as preventative measure to prohibit them from gaining access to eternal life indicates that their previous state of intimate friendship with God has been lost, along with the possibility of immortality.

Toews emphasis on what is not present in the text is significant in light of the excessive theological content that has been piled on this text and its interpretation in its rather complex Wirkungsgeschichte. This includes a complete lack of any association of the serpent with Satan or the demonic; the 
absence of sexual connotations; and the absence - in both English and Hebrew - of words such as "sin," "transgression," "rebellion," or "guilt.” Nowhere is it implied that Adam's moral condition suffers or is altered as a result of disobedience, or that the sin of Cain in Gen 4 should be understood in view of “a morally defective nature that he inherited from Adam” (p. 13). The narrative does not mention a "fall," that is, that "later Christian understanding which has been read back into the text” (p. 13).

If we should, then, draw conclusions about "sin" from this narrative in which neither sin nor transgression is named, it would consist of mistrust in and disobedience of God's instruction on the part of Adam and Even, with fractured relationships and estrangement resulting on all levels (i.e. from God, from each other, from some animals, and from nature). Such a relational view of sin and its effects is far removed indeed from the ontological understanding of sin that developed under Hellenistic influence.

In view of the fact that the Gen 3 narrative receives no reinterpretations - or even re-tellings - in the $\mathrm{HB}$, the significant amount of interpretive attention that it receives in Second Temple Judaism is striking. This forms the subject matter of Chapter Two, The Story of Sin in Second Temple Judaism (200 BCE-200 CE). The treatment of the narrative during these 400 years displays both development and diversity in interpretative tradition. The earlier literature from this period (Sirach, Wisdom of Solomon, Jubilees, Dead Sea Scrolls) portray Adam as a hero and wise man. He is a model of holiness, the first patriarch of the Jewish people, and in Jubilees even performs priestly duties before leaving (not being driven from) the Garden. These early textual witnesses of Second Temple Judaism sees Adam neither as the father of sin nor as the origin of death. Instead, these traditions understand sin to have originated with Cain (Sirach, Wisdom of Solomon), or with the lamented "marriage" between the "sons of God" and the "daughters of men" in Gen 6 (1 Enoch, Jubilees, Testament of the Twelve Patriarchs, Dead Sea Scrolls). In a bold claim by the Community Rule of the Dead Sea Scrolls, it is even suggested that this responsibility may lay with Godself, due to God's creation of an evil spirit that led to sin entering the world through Adam.

The traumatic events of $70 \mathrm{CE}$, when Jerusalem and the Temple suffered a second destruction, found literary expression through, among others, a different interpretation of the introduction of sin into the world. The Apocalyptic writers of 4 Ezra and 2 Baruch hold Adam responsible for this (only 2 Bar. 19:8 and 48:42 mention Eve in this regard). While universal death, as well as physical pain and the general state of chaos in the world follows as a consequence of sin, the act of sinning flows from a free choice and is therefore a matter of individual responsibility. The fact that the Apocalyptic writings at the end of the first or beginning of the second century CE unilaterally reject the notion of hereditary sinfulness, may indicate to us the existence of minority 
groups during this time that did propagate the hereditary transmission of sin from Adam. Turning our focus to Eve, we find yet more diversity in Second Temple literature. While one tradition holds Eve more responsible than Adam for the disobedience in the Garden (Jubilees, Josephus' Antiquities, Life of Adam and Eve), it is only the Life of Adam and Eve that associates illicit sexual desire with Eve's transgression. It is also in the Life of Adam and Eve, which strangely is the same document that holds Eve most responsible for the transgression in the Garden, that we also find a subversive portrayal of Eve as a virtuous model of morality.

In Chapter Three, The Story of Sin in the Jesus Movement: Paul the Follower of Jesus, Toews turns his attention to the mere 3 out of the 27 writings of the NT canon that make reference to the Adam and Eve story - all three to be found in the Pauline (or deutero-Pauline) corpus. Toews interprets the first two of these texts - 1 Cor 15:22 and Rom 5:12-19 - within the same apocalyptic framework that he did 4 Ezra and 2 Baruch. For Paul, the "present evil age" and the "age to come" are epitomised by the paradigmatic figures of Adam and Jesus:

Messiah Jesus' life, death and resurrection was God's apocalyptic answer to the apocalyptic power of Sin introduced by Adam into the world. History is really about two apocalyptic paradigmatic figures, Adam and Jesus. The life, death, and resurrection of Jesus was the apocalyptic event for Paul that the destruction of Jerusalem and the Temple was for 4 Ezra and 2 Baruch with one critical difference. The writers of 4 Ezra and 2 Baruch were trying to formulate a theodicy so that they and their people could hope again. Paul believed that the apocalyptic events of Jesus' life, death, and resurrection meant history now existed at the "mingling of the ages" (1 Cor 10:11 especially, and 2 Cor 5:16), that is, the overlap of the present evil age and the age to come (p. 41).

Paul's reframing of apocalyptic theology transformed Adam's transgression into an apocalyptic event that introduced the power of Sin into the cosmos and enslaved all humans and the entire cosmos to the power of universal, cosmic sinfulness. The consequence of this sin is the mortality in which all humans share, and yet all human persons remain responsible for their own sinful behaviour. Paul did not concern himself with questions about the transmission of sin, and he did not propagate hereditary sinfulness: Universal sinfulness was due to the cosmic power or rulership of Sin. It did not result from the biological transmission of sin from one generation to the next:

Sin in Paul is defined as a relational problem, or quite literally a political problem, the rulership of Sin, from which human beings and creation need liberation. Sin is not defined in ontological categories. Paul outlines a political theology of sin, not a metaphysical doctrine of $\sin ($ p. 46). 
Toew's reading of the Greek Fathers in Chapter Four marks the first chapter that bears the phrase "Original Sin" in the title: The Story of Original Sin in the Greek Church Fathers (ca. 150-400 CE). The Greek Fathers, nevertheless, do not know an ontological understanding of sin. For them, too, with their more positive outlook on human nature than the church in the west, sin results from freely committed acts that cause fractures in relationship. To this, however, the Greek Fathers added a "social hereditary" aspect, according to which such sinful acts are "nurtured by 'the social heredity' in which people are born and live, and results in broken relationships, personal dysfunction and social chaos, and ultimately death.” The Greek thinkers reveal a remarkable similarity in their interpretation of Gen 3, and while they are all in agreement that sin entered the human race due to Adam's transgression, their view of the implications thereof are quite different from that found in the Latin-speaking western churches. Most importantly, the Greek Fathers do not know inherited guilt. They all hold that, while humanity did inherit Adam's punishment (i.e. death and corruption), they did not inherit Adam's sin, for such guilt could only follow from a freely committed personal act. The Greek Fathers also had a tendency to allegorise Gen 3. They also tended to interpret Adam and Eve's transgression as the understandable error of imperfect, innocent children, and thought that this childish error thwarted their development into the mature creatures that God had planned for them to become. The consequences of Adam and Eve's disobedience was seen more in terms of moral weakness and the loss of the Holy Spirit's assistance, therefore deprivatio rather than depravatio: "a fundamental corruption or deformity of human nature” (p. 61). As mentioned above, the transmission of sin was conceived as social heredity rather than biological heredity; thus children brought up outside of paradise were left to the distorted examples of their parents. This was consistently accompanied, however, by an emphasis on free will and personal responsibility, even in the face of a tendency to explain the entrance of evil into the world as resulting from the malevolent assaults of Satan and demonic forces (rather than through abstract ideas of original sin). Finally, the Greek Fathers generally translated the $\dot{\phi} \phi$ ' $\tilde{\Psi}$ phrase in Rom 5:12 as “because of” rather than as "in whom."

Chapter 5, The Story of Original Sin in the Latin Church Fathers Prior to Augustine (200-400 CE), at once illustrates the profound difference between the Eastern and Western theologians of the early centuries, and demonstrates how Augustine's predecessors in the western church laid both the theoretical and rhetorical foundations for his doctrine of original sin:

From Tertullian forward the western fathers had a much more pessimistic anthropology, thanks, in part at least, to his linkage of the transmission of sin from Adam to his progeny through the traducian theory of the origin of the soul, and thus the concept of "seminal identity." Tertullian also introduced forensic categories for 
understanding sin as well as the important language of "original moral fault," originis vitium. Cyprian associated being "carnally born" with the "hereditary infection by sin" which needed the salvific washing of infant baptism. Ambrose transformed the unfallen Adam into a completely "Righteous" and "Perfect" "Superman" who "falls" in the Garden. He further linked Adam's sin with inherited guilt via the notion of the seminal identity with Adam's sin, and talked about "hereditary sins" (peccata hereditaria). Ambrosiaster added the critical exegetical proof-text with his mistranslation ["it is plain that all have sinned in Adam as in a lump (quasi in massa ...”)] of Romans 5:12. All the pieces of the puzzle were on the table, and even loosely assembled (p. 71).

Moving away from the eastern view of sin as relational, sin now became ontological, and something that is inherited. The one similarity still shared with the eastern church is that, still at this point at least, the western fathers managed, somewhat forcibly, to hold on to human free will and responsibility. Augustine would soon realise, however, that the determinism of ontological sin and human responsibility could not coexist, and so his theology of original sin had no room for free will.

Chapter 6, Augustine's Theology of Original Sin (354-430), outlines the development of Augustine's thought on original sin from his early formulation in reaction to Manichaeism, followed by his reaction to Pelagius, and considers the role of infant baptism before discussing the centre of Augustine's doctrine of original sin. It is Augustine that we have to thank for introducing the decisive phrase "original sin" (originale peccatum) in 397, along with "original guilt" (originalis reatus) and the "lump of sin" (massa peccati) that describes humanity, since all have died in Adam (1 Cor 15:22) (p. 74).

Augustine's argument for original sin rests, in part, on the (biblically unsupported) notion of an Adam that, pre-Fall, was righteous and perfect, possessing mental powers greater than the most brilliant philosophers and scientists. Due to Adam's choice, human nature was essentially changed and humanity universally condemned "because Adam's sin 'passed unto all men'”; it is original sin [peccatum originale] or transmitted sin [peccatum ex traduce] (p. 79), and it is because of this contamination of the soul that infants must be baptised. Yet Augustine understood this defilement of human nature to be so fundamental that it would not be corrected by baptism. Hence, the offspring of baptised parents would still suffer the blemish of Adam's transgression (p. 82).

Toews discusses two metaphors that play a critical role in Augustine's doctrine of original sin: vitium and reatus. Vitium is a medical metaphor that describes the hereditary moral disability that, since it has been acquired by Adam, is being transmitted from one generation to the next. Under the onslaught of concupiscence, the "tendency which drives human beings to turn 
from the supreme and unchangeable God to find satisfaction in the changeable, that is, in creatures," vitium meant the loss of free will (p. 82). Reatus, on the other hand, is a legal metaphor that affirms humanity's inherited legal liability and subjection to judicial punishment for Adam's sin. This "transfer of original guilt” was occasioned via seminal identity, according to which Adam included the whole of humanity in a physiological sense, since humanity as a whole would proceed from his genitals. While Augustine claimed that his doctrine of original sin was aligned with church tradition, his views differ greatly from that of the Eastern Church, and while his thought certainly had more parallels within the Western Church, it was really only Ambrose and Ambrosiaster whose ideas offered clear support for original sin as outlined by Augustine.

Both the idea of a perfect and righteous Adam and the theory of seminal identity are foreign to Scripture. For the former Augustine follows Ambrose, who constructed this mythology without any biblical basis whatsoever, and for the latter he builds on debates within Greco-Roman philosophy. Finally, the biblical basis for original sin itself fails completely:

Augustine grounds his theology in five biblical texts: Job 24:4-5 [faulty Latin translation from the LXX] [25:4-5 NRSV]; Psalm 51:5; John 3:5; Ephesians 2:5; Romans 5:12. Two of the proof-texts are based on mistranslations (Job and Romans), the use of the Ephesians texts is "specious," according to Rondet, and neither the Psalms nor the John texts support Augustine's idea of “original sin” (p. 85).

Toews final chapter, Chapter 7, Where Do We Go From Here? Toward a Constructive Proposal, offers three suggestions as a path toward a biblical theology of sin. In constructing these proposals, Toews first turns to the Bible in an effort to understand how the people of Israel and the early members of the Jesus movement understood sin. He then investigates faith traditions that, while they accept the normativity of the biblical canon (or at least part thereof, e.g. the TNK in the case of the Jewish people), remained untouched by Augustine's doctrine of original sin and his interpretation of Gen 3 (besides the Jewish tradition Toews considers the Eastern Orthodox and Anabaptist-Mennonite traditions). Finally, he surveys a number of contemporary theologians that have proposed hamartiologies that are not defined by Augustine's heritage. Here Toews considers Alistair McFadyen, Cornelius Plantinga, James McClendon, Stanley Grenz, and Thomas Finger.

Having taken his reader on a journey through time and its engagements with the ever acute question of human sin, Toews points toward a direction in theology that he believes will at the same time take serious the dire reality of human brokeness and yet move away from some of the detrimental effects of an ontological understanding of sin, such as that adopted by Augustine. Theologically Toew's work is significant, well thought through and relevant, and yet the book reads almost as a memoir of the author's personal journey of 
shouldering a religious heritage that he found both debilitating and unbiblical. This writing style makes the book accessible to the curious reader, and yet valuable to the scholar.

Yolande Steenkamp, Ph.D. Candidate, Department of Dogmatics and Christian Ethics, University of Pretoria, Private Bag X20, Hatfield, 0028, South Africa. Email: ysteenka@gmail.com.

\section{NUWE BOEKE VIR RESENSIE IN OLD TESTAMENT ESSAYS /}

\section{NEW BOOKS FOR REVIEW IN OLD TESTAMENT ESSAYS}

L. Juliana M. Claassens, Claiming her Dignity: Female Resistance in the Old Testament. Collegeville, MN.: Liturgical Press, 2016. xxvi + 165 pages, paperback, US\$31.49. ISBN 978-0-8146-8419-1.

Richard M. Gale, On the Nature and Existence of God. Cambridge Philosophy Classics. Cambridge: Cambridge University Press, 2016. xi + 337 pages, paperback, £14.99. ISBN 978-1-316-50710-0.

Garrett Galvin, David's Successors: Kingship in the Old Testament. Collegeville, MN.: Liturgical Press, 2016. xi + 173 pages, paperback, US\$24.95. ISBN 978-0-8146-8251-7.

Benjamin D. Giffone, 'Sit at my Right Hand': The Chronicler's Portrait of the Tribe of Benjamin in the Social context of Yehud. LHBOTS 628. London: Bloomsbury T\&T Clark, 2016. xviii + 270 pages, hardcover, £85.00. ISBN 978-0-56766-731-1.

John Goldingay, Reading Jesus’ Bible: How the New Testament Helps us Understand the Old Testament. Grand Rapids, MI.: Eerdmans, 2017. viii + 262 pages, paperback, US\$24.00 [£19.99]. ISBN 978-0-8028-7364-4.

Sidney Greidanus, Preaching Christ from the Psalms: Foundations for Expository Sermons in the Christian Year. Grand Rapids, MI.: Eerdmans, 2016. $\mathrm{xx}+595$ pages, paperback, US\$40.00 [£26.99]. ISBN 978-0-8028-7366-8.

Alan T. Levenson, Joseph: Portraits through the ages. Philadelphia: The Jewish Publication Society / Lincoln: University of Nebraska Press, 2016. xxvii + 284 pages, hard cover with dust jacket, US\$32.95 £27.99. ISBN 978-0-82761250-1. 
William S. Morrow, An Introduction to Biblical Law. Grand Rapids, MI.: Eerdmans, 2017. xvi + 270 pages, paperback, US\$24.00 [£19.99]. ISBN 978-08028-6856-7.

Johanna Stiebert, First-Degree Incest and the Hebrew Bible: Sex in the Bible. LHBOTS 596. London: Bloomsbury T\&T Clark, 2016. xii + 228 pages, hardcover, £12.75. ISBN 978-0-56760-033-2. 